\title{
GEOGRAFIA DA ENERGIA
}

Teresa Barata SAlgueiro ${ }^{1}$

As questões da energia interessam a todos os cidadãos, pois as nossas sociedades são cada vez mais energio-dependentes e a energia é causa de importantes lutas políticas, desde as manifestações contra a localização de certas instalações à guerra do Iraque.

Existe hoje muita informação, proveniente de diversas fontes, muitas vezes contraditórias, mas gerou-se a ideia de que se trata de um problema eminentemente técnico, portanto inacessível aos não iniciados.

A publicação de um novo livro sobre as questões energéticas enquadra-se no modo como B. Mérenne-Schoumaker encara a Geografia, como conhecimento útil para "compreender o mundo, de modo a que os alunos possam situar-se face aos desafios sociais e espaciais, e adquirir saberes, saberes-fazer, competências e atitudes que lhes permitam agir com responsabilidade" (Mérenne-Schoumaker, 2002:7). O objectivo é, portanto, oferecer aos estudantes do $1 .^{\circ}$ ciclo a possibilidade de compreender esta questão tão fundamental para as nossas vidas.

A capacidade de síntese e de organização da autora traduzem-se numa obra de espectro largo e fácil leitura, que torna simples um problema que parece demasiado complexo, mesmo para o cidadão informado, que permite equacionar os diversos aspectos que estão em causa, no sentido de ajudar a formar uma opinião.

Mérenne-Schoumaker considera que a energia levanta problemas técnicos, pois tem de ser produzida e transportada até aos consumidores e estas operações implicam máquinas e operações complexas. Mas é também uma questão económica e política, devido à especificidade dos mercados, fixação dos preços e estratégias políticas adoptadas pelos diferentes actores que interferem nos mercados. É também um problema geográfico de primeira importância porque as fontes de energia são localizadas, o que implica transporte entre lugar de produção e de consumo, além de que a produção tem importantes consequências na organização espacial dos territórios (veja-se, por exemplo o porto-refinaria em Sines) e nos equilíbrios ambientais. Se é difícil conceber a vida em sociedade sem energia e se o aumento brutal das necessidades energéticas é uma das características das sociedades modernas, também é claro que a produção e o consumo

1 Professora na Faculdade de Letras da Universidade de Lisboa e Investigadora do Centro de Estudos Geográficos de Lisboa. E-mail: tbs@fl.ul.pt 
de energia têm muitos impactes no ambiente, e a consciencialização deste facto tem crescido consideravelmente nos últimos anos.

Em relação a uma obra publicada em 1993, encontramos importantes diferenças no conteúdo e no modo de apresentação. No que respeita ao conteúdo, deve salientar-se a maior importância dada às energias renováveis e às questões ambientais, para além do alargamento da bibliografia, inicialmente restrita a obras de geógrafos, e agora com largo recurso a sítios da Internet. A organização do volume também aparece ligeiramente modificada. Os capítulos são sensivelmente os mesmos, mas a sua disposição foi alterada, principalmente no que consideramos a $3 .^{\text {a }}$ parte, a que diz respeito aos mercados (relação produção/consumo).

Em termos de apresentação este livro traduz a evolução do ensino universitário para uma pedagogia mais centrada no aluno e nas aprendizagens. Assim, cada capítulo começa sempre com a inclusão de dois documentos constituídos por um texto mais ou menos ilustrado, para sensibilizar os leitores para a problemática tratada, seguida de uma breve análise onde a autora identifica as questões colocadas pelo texto e depois de uma breve síntese. Todos os capítulos têm uma conclusão em frases curtas, ao contrário da 1. ${ }^{a}$ edição, onde isso nem sempre acontecia. A introdução de uma cor, concretamente o verde, não nos parece muito feliz porque algumas figuras ficam muito escuras não ganhando em clareza face à edição anterior.

O livro desenvolve-se ao longo de 4 partes, para além das breves introdução e conclusão geral. Na primeira parte (cap.1), a autora apresenta as noções de base, a sua importância geográfica e o papel da geografia neste estudo. A segunda parte (caps. 2 e 3) diz respeito aos recursos energéticos e sua formação. Nestes capítulos faz-se a ponte entre a geografia económica e a geografia física, ao explicar a formação das jazidas de petróleo e carvão ou as diferentes condições naturais favoráveis à produção de electricidade, mas também a ligação com a engenharia de minas, ao tratar da exploração e da qualidade dos recursos, matéria onde, por vezes, o detalhe me pareceu excessivo. A terceira parte é dedicada aos mercados da energia. A autora começa pelo consumo e pela suas flutuações ao longo do tempo e no espaço, em articulação com a evolução dos usos atribuídos às diferentes formas de energia, para depois analisar a geografia da produção e a respectiva evolução no tempo; num terceiro momento reporta-se ao funcionamento dos mercados e à questão da fixação dos preços, o que a obriga a estudar os principais actores (empresas privados, Estados e organizações) e as respectivas estratégias, não raro em conflito. Finalmente a última parte trata das relações/impactes da produção e consumo das diferentes formas de energia no ambiente e de pistas para o futuro.

Objectiva mas mais cautelosa do que na 1 a $^{\text {a }}$ edição, Mérenne-Schoumaker mostra-nos que a evolução é muito dependente do avanço tecnológico e que não há respostas simples e únicas para os problemas, não se podendo dizer com clareza qual, ou como, vai ser o futuro.

\section{BIBLIOGRAFIA}

Mérenne-Schoumaker B (2007) Géographie de l'énergie. Acteurs, lieux et enjeux. Belin, Paris.

Mérenne-Schoumaker B (2002) Analyser les territoires. Savoirs et outils. Presses Universitaires de Rennes. Rennes.

Mérenne-Schoumaker B (1993) Géographie de l'énergie. Nathan, Paris. 